\title{
Legeforeningen og barnefamiliene
}

\author{
Legeforeningen har gått inn for å avvikle dagens turnusordning til fordel for basistjeneste. Dette vil ramme \\ barnefamilier og alenefors $ø$ rgere, som tidligere har vært ivaretatt gjennom henholdsvis barneplassordningen \\ og særplassregelverket.
}

Legeforeningens sentralstyre vedtok 16.2. 2011 å gå inn for å avvikle dagens turnusordning og erstatte den med søknadsbaserte nybegynnerstillinger (basistjeneste), i tråd med Helse- og omsorgsministerens forslag. Legeforeningen har imidlertid ikke anbefalt å videreføre det eksisterende regelverk i turnusordningen som tilrettelegger for aleneforsørgere spesielt og legeforeldre med skolebarn generelt.

\section{Dagens regelverk}

Gjennom fleksible permisjonsordninger og økonomisk støtte forsøker det offentlige Norge å legge til rette for at flere studenter skal få barn.. Årsaken er selvfølgelig at det rent biologisk er mest gunstig å få barn i 20-årene. Mange legestudenter får barn, og en god del har barn innen studieoppstart - barn som allerede er eller vil være i skolepliktig alder når det skal søkes om nybegynnerstilling.

Per i dag kan turnusleger med barn i skolealder søke om barneplass. Disse plassene administreres av turnuskomiteen ved det enkelte fakultet. I tillegg åpner turnuslovgivningen for særplass for bl.a. enslige forsørgere til barn under 12 år. Dagens regelverk sikrer forst og fremst barna et trygt/forutsigbart oppvekstmiljø og en stabil skolegang. I den aktuelle turnusdebatten synes dette aspektet å være neglisjert.

\section{Barna blir skadelidende}

Siden basistjeneste blir et krav for videre fagspesialisering, vil de fleste kandidater ønske en nybegynnerstilling etter endt utdanning. Når arbeidsgiver avgjør innstillingsrekkefølgen, vil ikke nødvendigvis leger med barn være en attraktiv søkergruppe. Tvert imot risikerer de å stille svakere i søknadsprosessen, da familielivet ofte har lagt naturlige begrensninger på arbeids- og/eller forskningserfaring.

Samtidig vil det for mange familier være praktisk umulig å flytte, siden ektefelle/ samboer ikke får tilsvarende jobb på det nye stedet. Dersom flytting lar seg gjennomføre praktisk og økonomisk, vil det like fullt kunne få alvorlige konsekvenser for barna. De tas ut av sitt etablerte miljø og skolesituasjon, hvilket kan påvirke trygghet, selvfølelse og evne til relasjonsbygging negativt. Enkelte barn har spesielle behov som gjør dem ekstra sårbare for forandring, andre har sykdom med etablert behandling/oppfølging som det vil være direkte skadelig og uansvarlig å ta dem ut av.

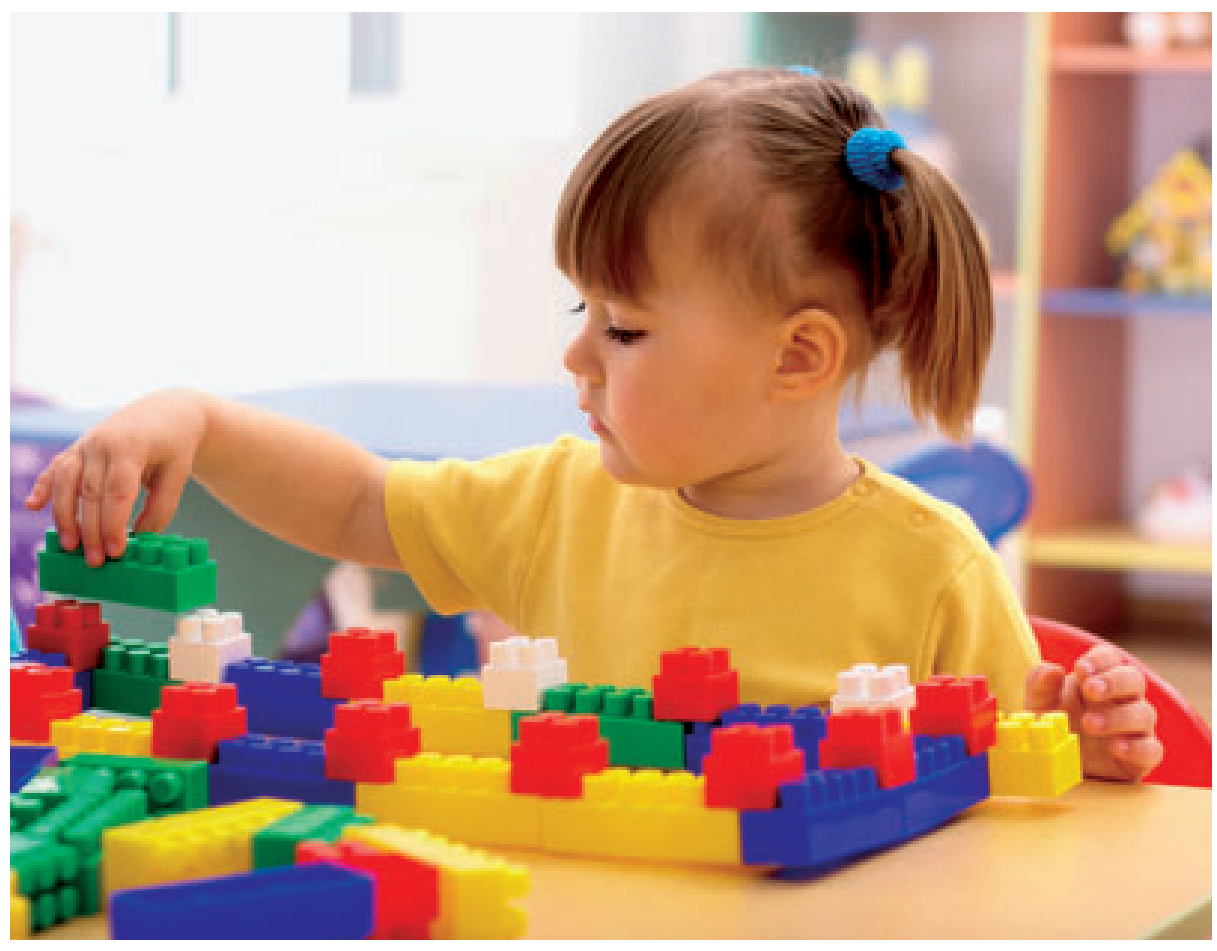

Illustrasjonsfoto Istockphoto

Slike potensielt uheldige konsekvenser for affiserte barn er ingen tjent med!

\section{Mulige konsekvenser}

- Mener Legeforeningen at legeforeldre i overnevnte kategorier rett og slett må regne med å være separert fra ektefelle og familie i halvannet år hvis de ønsker en fremtidig karriere?

- Blir konsekvensen at mange må ta kortvarige vikariater over flere år i påvente av potensiell innstilling til nybegynnerstilling?

- Eller - verre - kan det føre til at denne gruppen nyutdannede leger risikerer ikke å få påbegynt basistjeneste overhodet og dermed mister muligheten for spesialisering pga. begrenset evne til geografisk forflytning?

Innføring av basistjeneste uten at eksisterende ordninger videreføres kan føre til at færre legestudenter får barn under studietiden - stikk i strid med regjeringens politikk. I forbindelse med omleggingsprosessen som nå står for døren, bør Legeforeningen etter mitt syn gå inn for å opprettholde dagens barneplassordning generelt og regelverket for aleneforsørgere/leger med syke barn spesielt. Som et minimum bør regelverket videreføres i en overgangsperiode som strekker seg over flere år. Vi er mange som hittil i studieforløpet, kanskje allerede før studieoppstart, har basert oss og vår familieplanlegging på vissheten om eksisterende ordninger ved innvilget turnus. Jeg oppfordrer Legeforeningen på det sterkeste til å ta tak i problemet og jobbe for en videreføring av dagens barneplassordning og særplassregelverk. Barna bør fremdeles ivaretas!

\section{Kathrine Fodstad}

kathrine.fodstad@medisin.uio.no

Kathrine Fodstad (f. 1974) er medisinstudent ved Universitetet i Oslo og forskerlinjestipendiat ved Forskningssenter for fødselshjelp og kvinnesykdommer ved Oslo universitetssykehus, Ullevål.

Ingen oppgitte interessekonflikter.

Mottatt 18.3. 2011, første revisjon innsendt 5.4. 2011, godkjent 5.5. 2011. Medisinsk redaktør Anne Kveim Lie. 